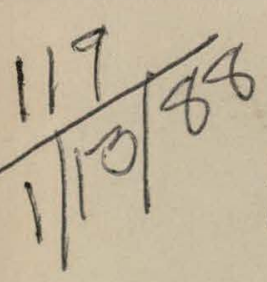

RFP-4141

October 5, 1987

\title{
AUTOMATED SATURATED STANDARD CELL INTERCOMPARISON
}

B. E. Bell

\section{DO ROT MCROFLM COVER}

\section{Rockwell International}

\author{
North American Space Operations \\ Rocky Flats Plant \\ P.O. Box 464 \\ Golden, Colorado 80402-0464
}

U. S. DEPARTMENT OF ENERGY

CONTAACT DE-AC04-76DPO3533 


\section{DISCLAIMER}

This report was prepared as an account of work sponsored by an agency of the United States Government. Neither the United States Government nor any agency Thereof, nor any of their employees, makes any warranty, express or implied, or assumes any legal liability or responsibility for the accuracy, completeness, or usefulness of any information, apparatus, product, or process disclosed, or represents that its use would not infringe privately owned rights. Reference herein to any specific commercial product, process, or service by trade name, trademark, manufacturer, or otherwise does not necessarily constitute or imply its endorsement, recommendation, or favoring by the United States Government or any agency thereof. The views and opinions of authors expressed herein do not necessarily state or reflect those of the United States Government or any agency thereof. 


\section{DISCLAIMER}

Portions of this document may be illegible in electronic image products. Images are produced from the best available original document. 


\section{DISCLAIMER}

"This report was prepared as an account of work sponsored by an agency of the United States Government. Neither the United States Government nor any agency thereof, nor any of their employees, makes any warranty, express or implied, or assumes any legal liability or responsibility for the accuracy, completeness, or usefulness of any information, apparatus, product, or process disclosed, or represents that its use would not infringe privately owned rights. Reference herein to any specific commercial product, process, or service by trade name, trademark, manufacturer, or otherwise, does not necessarily constitute or imply its endorsement, recommendation, or favoring by the United States Government or any agency thereof. The views and opinions of authors expressed herein do not necessarily state or reflect those of the United States Government or any agency thereof."

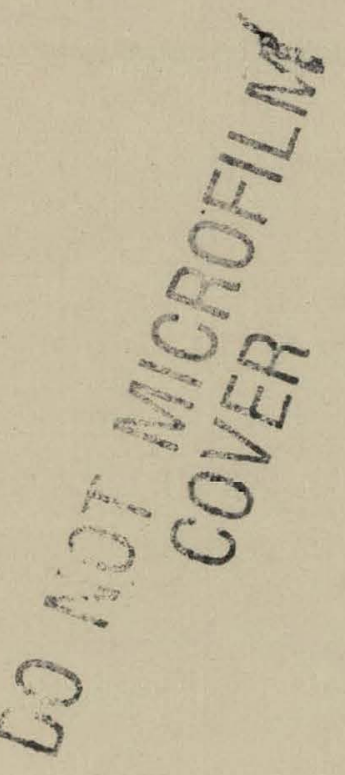

Printed in the United States of America

Available from the

National Technical Information Service

U.S. Department of Commerce

Springfield, Virginia 22161

Price Code: 001-025 pages, Code A02

Price Code: $026-050$ pages, Code A03

Price Code: 051-075 pages, Code A04

Price Code: 076-100 pages, Code A05

Price Code: 101-125 pages, Code A06 
Printed

\title{
AUTOMATED SATURATED STANDARD CELL INTERCOMPARISON
}

\author{
B. E. Bell
}

C. A. Deitesfeld, Editor

I. C. Delaney, Compositor

\section{DISCLAIMER}

This report was prepared as an account of work sponsored by an agency of the United States Government. Neither the United States Government nor any agency thereof, nor any of their employees, makes any warranty, express or implied, or assumes any legal liability or responsibility for the accuracy, completeness, or usefulness of any information, apparatus, product, or process disclosed, or represents that its use would not infringe privately owned rights. Reference herein to any specific commercial product, process, or service by trade name, trademark, manufacturer, or otherwise does not necessarily constitute or imply its endorsement, recommendation, or favoring by the United States Government or any agency thereof. The views and opinions of authors expressed herein do not necessarily state or reflect those of the Uniter States Government or any agency thereof.

\section{SUBJECT DESCRIPTORS}

Automated Cell Intercomparison

ROCKWELL INTERNATIONAL

NORTH AMERICAN SPACE OPERATIONS ROCKY FLATS PLANT

P. O. BOX 464

GOLDEN, COLORADO $80402-0464$

Prepared under Contract DE-AC04-76DPO3533

for the

Albuquerque Operations Office 
RFP-4141

$$
\begin{gathered}
\text { OO NOT MICROFILM } \\
\text { THIS PAGE }
\end{gathered}
$$

.

jj 


\section{CONTENTS}

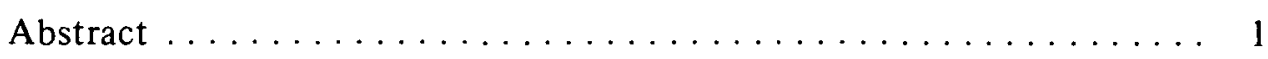

Introduction $\ldots \ldots \ldots \ldots \ldots \ldots \ldots \ldots \ldots \ldots \ldots \ldots \ldots \ldots$

Cost to Implement and Benefits Derived. . . . . . . . . . . . 1

Tangible Benefit $\ldots \ldots \ldots \ldots \ldots \ldots \ldots \ldots \ldots$

Intangible Benefit $\ldots \ldots \ldots \ldots \ldots \ldots \ldots \ldots \ldots \ldots \ldots \ldots \ldots \ldots \ldots$

Additional Benefit. . . . . . . . . . . . . . . . . 2

Problems Encountered $\ldots \ldots \ldots \ldots \ldots \ldots \ldots \ldots \ldots \ldots \ldots \ldots \ldots$

Cell Intercomparison. . . . . . . . . . . . . . . 7

Manual Intercomparison . . . . . . . . . . . . . 7

Automated Intercomparison . . . . . . . . . . . 7

Comparison: Automatcd Versus Manual . ........... 8

Conclusions. . . . . . . . . . . . . . . . .

Appendix A. . . . . . . . . . . . . . . . . . 11 
RFP-4141 


\section{F I G U R E S}

1. Bank $3102 \cdot$ Versus Bank 3101 :

Standard Deviation and L-R Component . . . . . . . . 3

2. Bank 3102 Versus Bank 3101 Measured

in Microvolts $8 / 19 / 85$ Through $7 / 29 / 86 \ldots \ldots \ldots \ldots \ldots$

3. Manual Intercomparison: Bank 3102 Versus

Bank 3101 Standard Deviation and L-R Component ....... 5

4. Automated Intercomparison: Bank 3102 Versus

Bank 3101 Standard Deviation and L-R Component . . . . . . 6

5. Standard Cell Manual Measurement Block Diagram. . . . . . . . 7

6. Standard Cell Automatic Measurement Block Diagram . . . . . . . 7

7. Bank 3102 Versus Bank 3101 Measured

in Microvolts $7 / 11 / 86$ Through $3 / 30 / 87 \ldots \ldots \ldots \ldots . \ldots 8$

\section{T A B L E}

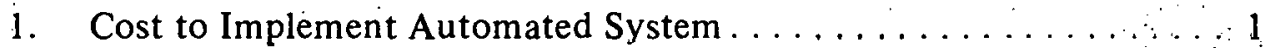

A P. P E N D I X

Appendix A. Sample Automated Measurement"Program 


\section{A CKNOWLEDGMENTS}

I would like to acknowledge technicians G. Blood and G. Brown. Without their programming expertise and extensive data taking this project would have taken much longer. 


\title{
AUTOMATED SATURATED STANDARD CELL INTERCOMPARISON
}

\author{
B. E. Bell
}

\begin{abstract}
A cost effective, highly efficient, and automatic method of intercomparing standard cells has been sought after and implemented, utilizing computer control and a commercially available scanner. This system reduces intercomparison time from 4 hours to 30 minutes using the standard National Bureau of Standards (NBS) $4 \times 4$ design.
\end{abstract}

\section{INTRODUCTION}

Manual intercomparison of saturated standard cells can yield very accurate results, on the order of tenths of parts per million. Typically our cells receive an uncertainty. of \pm 3 to \pm 5 parts per million microvolts from the Primary Standards Laboratory (PSL).

Standard practice is to make intercomparisons monthly due to the long time involved in taking the measurements. However, occasions arise when more frequent intercomparisons are desirable. These include laboratory environmental upset, physical transfer of the cells, monitoring after cell bath general maintenance, and general historical data gathering.

With assigned uncertainties of \pm 3 to \pm 5 microvolts, a method was needed to intercompare cells in a time efficient manner without impacting these already wide tolerances assigned by the PSL.

The National Bureau of Standards (NBS) was contacted and queried regarding available scanners or automated systems. They confirmed the availability of a scanner, specifically applicable to standard cell intercomparison, that they had tested with encouraging results.

The designer and builder of the Data Proof scanner was contacted, technical information was supplied, and the scanner was chosen for inplementation and evaluation.

\section{COST TO IMPLEMENT, AND BENEFITS DERIVED}

Implementation was a rather painless task. After the scanner was received, it was connected to the cells and to the digital voltmeter input terminals using low thermal wire. Connection to the computer was accomplished using IEEE-488 cables. Interconnection was relatively simple.

Most standards labs use NBS-generated software. The same is true for Rocky Flats Plant, depending upon the application. For automated intercomparison, scanner channel selection and digital voltmeter commands had to be incorporated into the existing NBS software.

Once the system was fully assembled, and the software generated, evaluation and testing began. Various voltmeters were evaluated for best sensitivity and resolution. Types of physical connections were examined to reduce thermal electromotive force (emf) generation.

Table I shows the implementation costs. No new ancillary equipment was required - - costs only reflect the price of the scanner.

\section{Tangible Benefit}

Implementation of this system saves 44 hours of technician time per year.

TABLE 1. Cost to Implement Automated System

\begin{tabular}{|c|c|}
\hline Data Proof Scanner & $\$ 3,500$ \\
\hline Modification of existing software (16 hr) & 272 \\
\hline Software testing $(6 \mathrm{hr})$ & 102 \\
\hline Hardware testing $(40 \mathrm{hr})$ & 680 \\
\hline SysteJn lesting $(60 \mathrm{hr})$ & 1,020 \\
\hline & $\$ 5,574$ \\
\hline
\end{tabular}

Data Proof Scanner

Modification of existing software $(16 \mathrm{hr})$

Total
3,500

102

680

$\$ 5,574$ 


\section{Intangible Benefit}

The new system has several intangible benefits. It promotes flexibility in use of personnel. Previously, only highly experienced and highly trained technicians could perform this measurement. Use of the new method with computer control and prompting allows most metrology technicians to perform this precise measurement with little or no specialized training.

It also provides for the maintenance of the most complete history possible. Previously, due to the lengthy nature of the measurement, only one standard cell intercomparison per month was possible or practical. Now, readings can be taken every half hour, if desired, to pinpoint inconsistencies between standard cells or to track single cell events.

Flexibility to evaluate the effects of various measurement variables is a noteworthy attribute. This could include data averaging (optimum number of points to average), effect of meter zeroing versus nonzeroing, and optimum time of day to make the intercomparisons.

Another positive feature is elimination of human error associated with reading measurements, transcribing data, and performing calculations.

\section{Additional Benefit}

Two additional benefits result from the new system. First, the system is expandable; it can incorporate a database management system linked to graphics sottware for total data manipulation and historical/statistical graphics. This would eliminate time-consuming plotting and the incvitablc human errors involved.

Second, the new system provides a safer means of data storage to maintain historical control. This includes disk storage as well as hard copy in a localized file.

\section{PROBLEMS ENCOUNTERED}

Initially, meter selection posed a minor problem. Two Hewlett Packard 3456s worked quite well.
They were easy to program for and quite compatible with the HP86A computer controller, but they were used quite extensively for other measurements and could not be dedicated to a single system. The samc hcld true for our two Solartron 7081 meters. However, a Keithley 181 nanovoltmeter had good sensitivity and resolution and was available for dedication to a single measurement system.

The main system components were selected and testing began. Straightforward measurements were tried at first; that is, a sequential selection of scanner relays linking various combinations of cclls together per the NBS $4 \times 4$ design. Erratic rcsults were produced. Ccll valucs, lcft-right components, and standard deviations all fluctuated. To smooth out the errors, averaging 5 to 10 readings was attempted. Cell values appeared to be well within the limits set by the PSL. Readings were carried on almost daily for at least several months. No anomalies were apparent in the measured cell values. However, a fluctuating standard deviation did appear (ranging from -0.5 to +0.5 microvolts), as did a fluctuating left-right component (ranging from -0.2 to +0.2 microvolts). See Figures 1 and 2 . In both figures, notc the cxtreme excursion beginning around $3 / 27 / 86$. This excursion occurred due to laboratory environmental upset, where temperature increased to a point well beyond laboratory specifications. Comparing these values and manual readings previously taken with the Guildline 9930 Direct Current Comparator Potentiometer, the latter clustered right around zero microvolts, and was generally much less than 0.2 microvolts, as shown in Figure 3.

The problem indicators had the same characteristics as those linked to induced thermal emfs caused by ponr physical connections. However, there were no suspect problem connections, such as an external terminal block. The only physical connections were those tied directly to cell terminals. These connections should not have affected our readings to the extent observed.

To reduce the frequency of measurement excursions, we decided to change the measurement technique. The idea was to measure the difference of two cells, with cell " $A$ " connected to one side of the meter, for example the positive side, and 


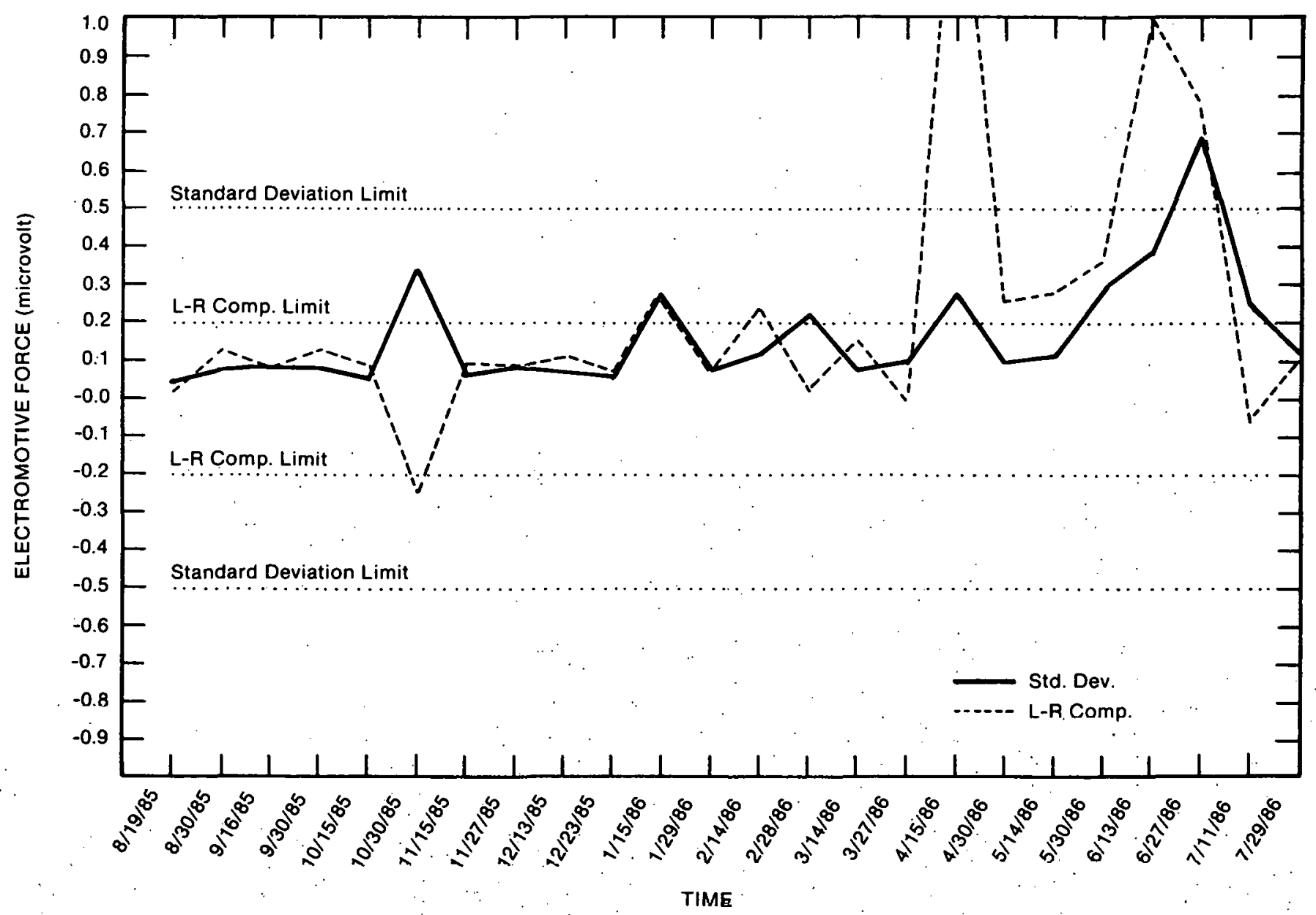

FIGURE 1. Bank 3102 Versus Bank 3101:'Standard Deviation and L-R Component 


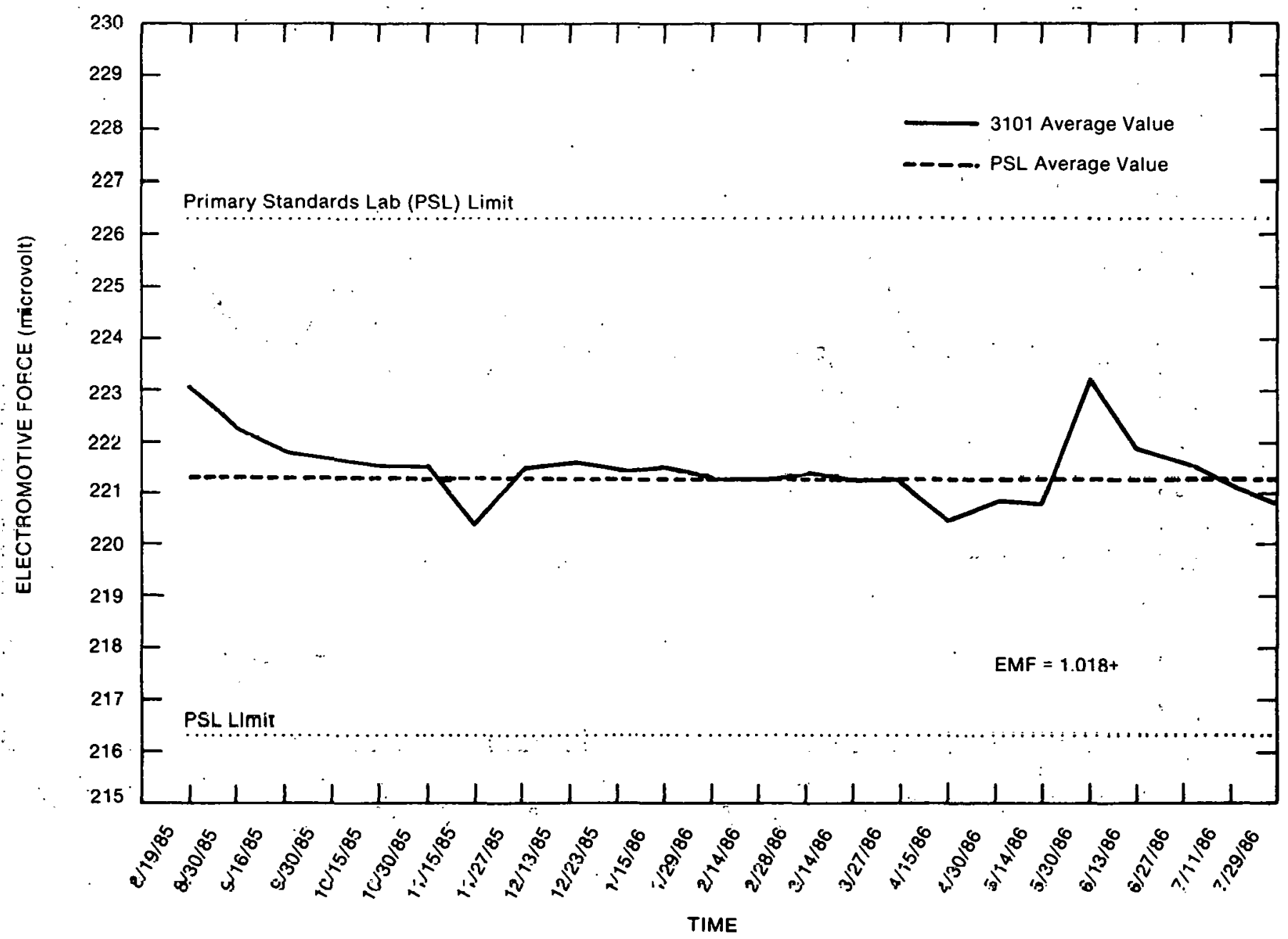

FIGURE 2. Bank 3102 Versus Bank 3101 Measured in Microvolts 8/19/85 Through 7/29/86 


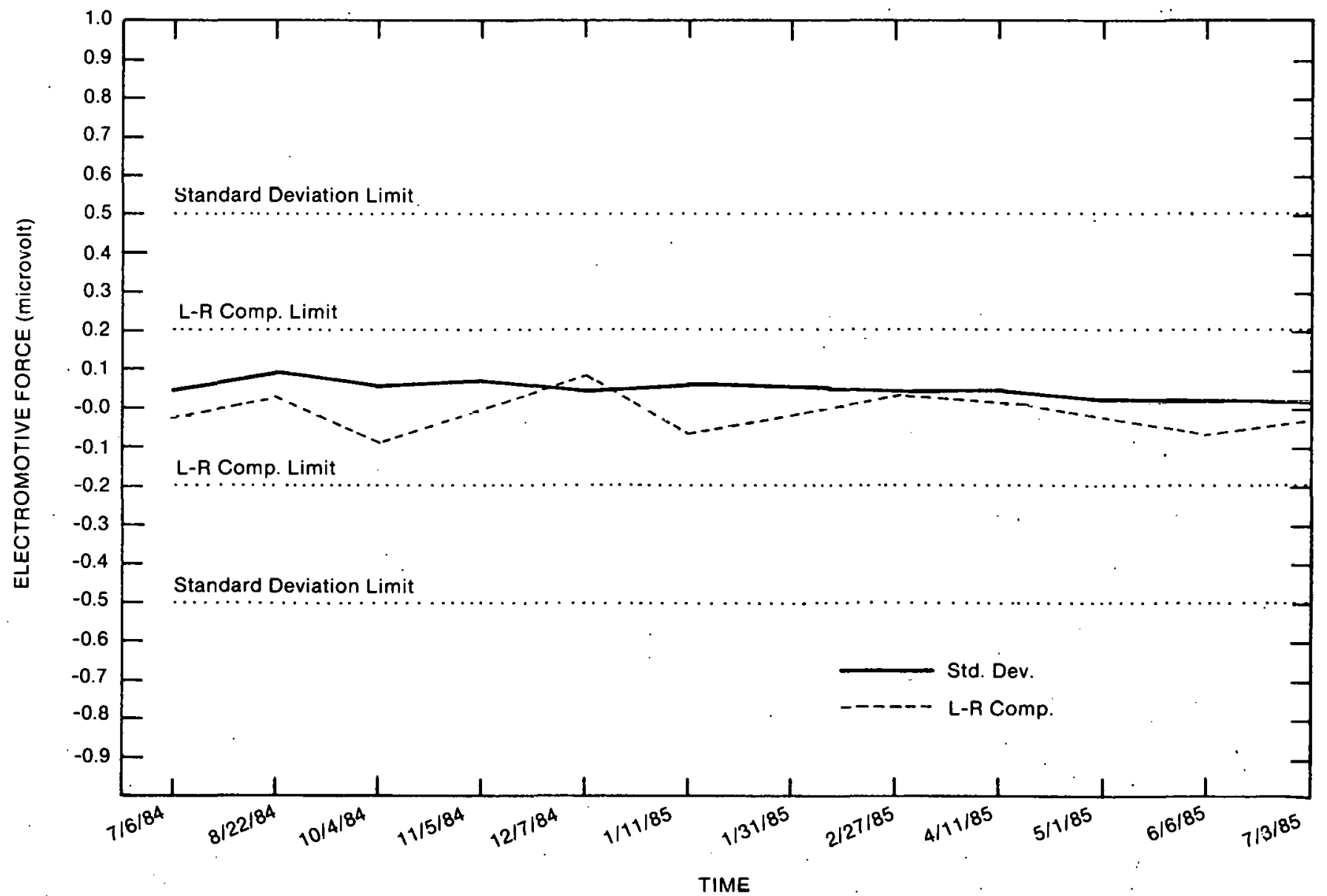

FIGURE 3. Manual Intercomparison: Bank 3102 Versus Bank 3101 Standard Deviation and L-R Component 
cell " $\mathrm{B}$ " connected to the negative, and take a series of measurements. The final steps were to reverse the cells' connections to the meter (via the scanner), take another series of readings, average the magnitude of the readings, and assign the proper sign.

This appeared to work very well, and manual readings were halted, except to confirm measurement integrity. From July 1986 to January 1987, automatic intercomparisons were continually made. Excursions could still be periodically observed on the left-right component and standard deviation. The excursions appeared to be too infrequent to be thermals. Random line transients were our first suspects for investigation. Our less than clean power source has affected sensitive measurements in the past. The main problem is that with manual measurements, the metrologist can pause for a transient to pass. By contrast, automated systems continue, despite the transient. Therefore, we decided to begin manual readings again, pair them up with the automated measurements, and compare the results.

During the manual measurement of one such session, when cell enclosure heaters came on, excursions occurred in the data, excursions dependent upon random occurrences of simultaneous measurement and heating. Apparently, AC line power causing inductive reactance in the heating elements, produced transients affecting the measurements. The solution proved simple. During all future intercomparisons, battery power will be used for heater element power. Figure 4

FIGURE 4. Automated Intercomparison: Bank 3102 Versus Bank 3101 Standard Deviation and L-R Component

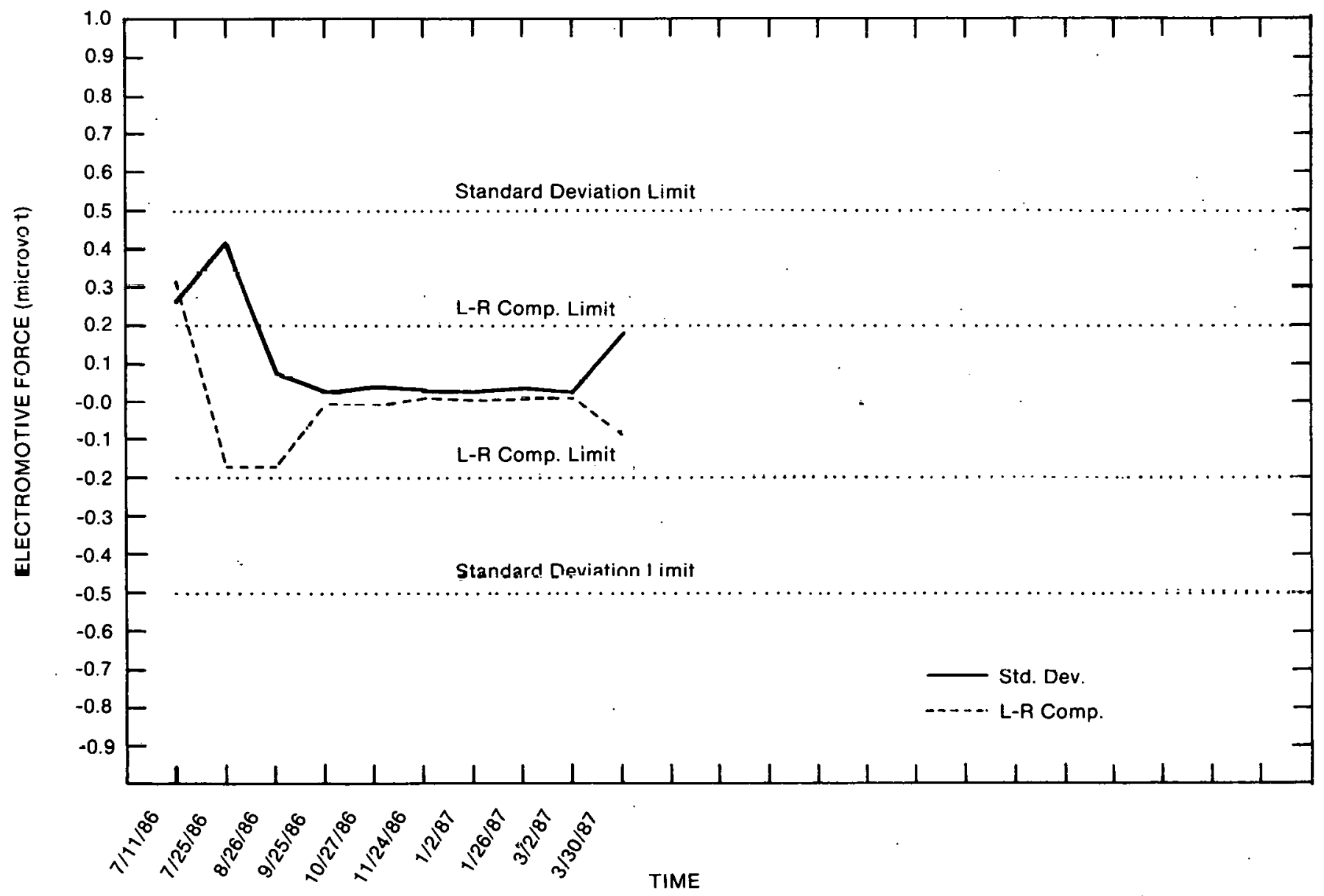


shows the relative measurement stability upon implementing this policy in January 1987. To date, it appears that left-right component and standard deviation fluctuations have been eliminated, but we will continue to monitor the system for consistency.

\section{CELL INTERCOMPARISON}

The main difference between components of a manual intercomparison and an automated intercomparison is that to automate, the metrologist and manual switch are replaced by a computer and a bus controllable scanner, respectively. Figures 5 and 6 are block diagrams of the two intercomparisons. However, in this instance, since uncertainties were based upon the PSL intercomparison and since the Guildline 9930 was not bus controllable, it was replaced with a bus controllable voltmeter.

\section{Manual Intercomparison}

All cell banks being intercompared are connected to manual switches. From this point, they are connected to the Guildline 9930 potentiometer. When predetermined switch settings are selected, certain desired cells are bucked against one another. At this point, the technician must balance the bridge, note the dial reading, and record the data point as a difference reading. These steps must be accomplished for each cell in every bank used as a standard, and are dependent upon the NBS measurement design used.

After all readings have been taken, the temperature of each cell bank must be recorded. This record is needed for the temperature compensation factor used in the calculations - - the final step of the intercomparison (except for plotting).

Calculations are performed using NBS statistical analysis software. This software must be loaded into the computer with all manual measurements. and temperature values typed in by the metrologist, as prompted. When the program finishes the

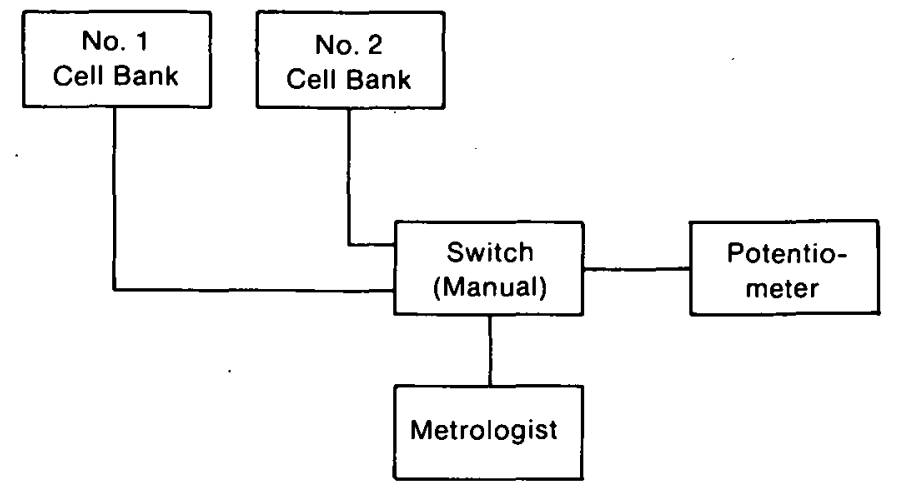

FIGURE 5. Standard Cell Manual Measurement Block Diagram

FIGURE 6. Standard Cell Automatic Measurement Block Diagram

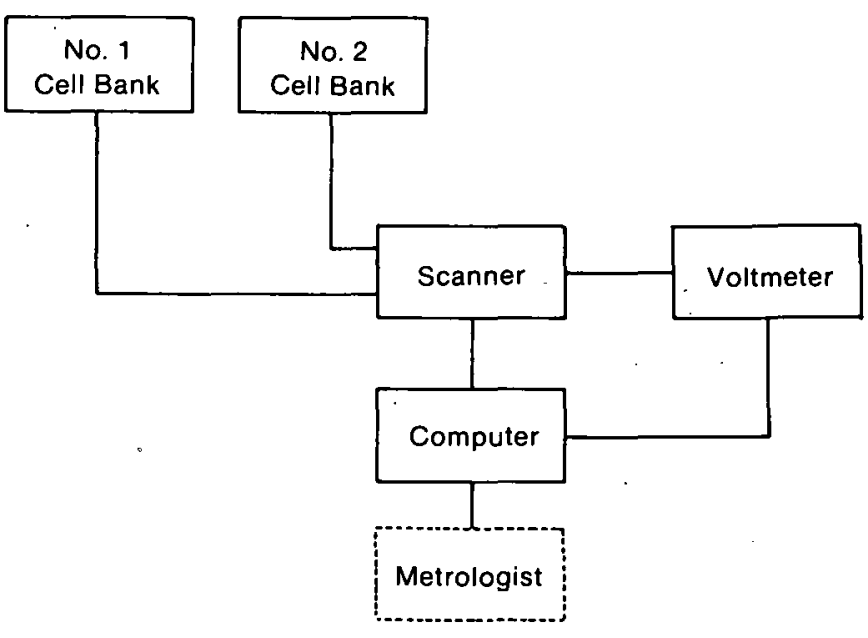

computations, a final report is output containing saturated standard cell values to compare to assigned PSL values.

\section{Automated Intercomparison}

All cell banks being intercompared are connected to the scanner. From this point they are connected to the digital voltmeter. Both scanner and voltmeter are connected, via IEEE-488 bus, to a controlling computer. When predetermined scanner relays are selected (by computer), certain desired cells are bucked against one another and the computer controlled voltmeter measures the value and sends it to the computer. This is accomplished for each cell in every bank used as 


\section{RFP-4141}

a standard, and is also dependent upon the NBS measurement design used.

After all readings have been taken, the computer prompts the metrologist to input each cell bank temperature, as required in the manual intercomparison, for temperature compensation used in the calculations.

Next, the computer automatically performs the NBS statistical analysis routine and a final report is generated. Please see Appendix A, the sample automated measurement program.

\section{Comparison: Automated Versus Manual}

As was shown in the previous section, the main difference between manual and automated measurements is the replacement of switches, potentiometer, and metrologist with a scanner, voltmeter, and computer.

What benefit does automating standard cell intercomparisons provide a standards laboratory? It saves time. How much time is saved depends on the number of banks of cells being in tercompared and how often the intercomparison is accomplished. In this application, using a typical $4 \times 4$ NBS design, automation was faster by a factor of 8 to 1 .

Tu carry this un a bit further, tinc was saved, and at the same time, the integrity of the measurement. was maintained. That is, accuracy did not suffer. Figures 3 and 4 provide a comparison of manual and automated measurements. Figures 4 and 7

FIGURE 7. Bank 3102 Versus Bank 3101 Measured in Microvolts 7/11/86 Through 3/30/87

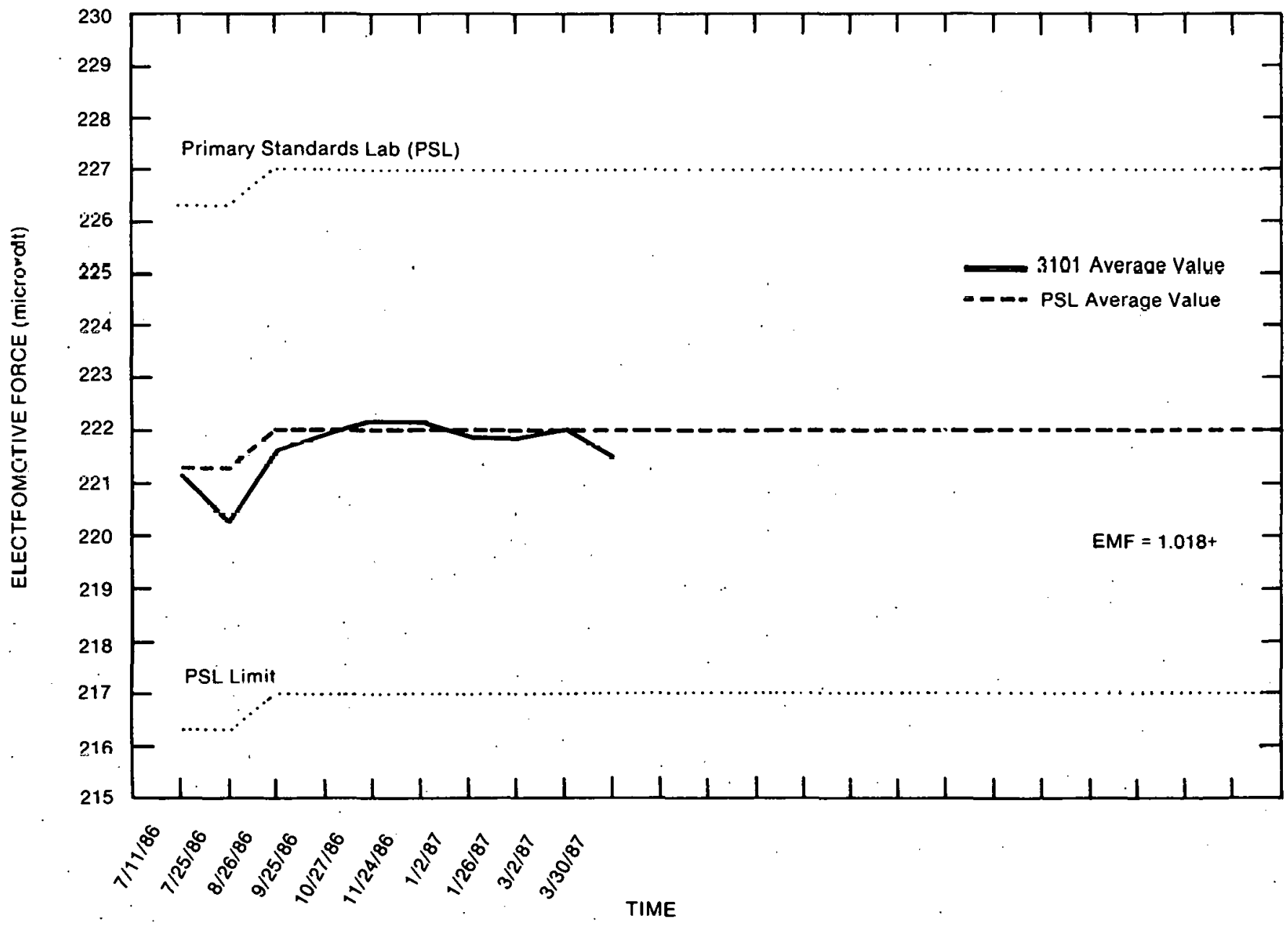


show how well automated measurements preserve the stability, precision, and accuracy because they conform to the PSL-generated values and lie between the \pm 3 and \pm 5 microvolt tolerance bands.

\section{CONCLUSIONS}

A solution was sought to free up valuable measurement time and eliminate human error associated with saturated standard cell intercomparisons. The method tested utilized standard laboratory equipment and a commercially available standard cell scanner.

All evidence supports that when dealing with control limits on the order of \pm 3 to \pm 5 microvolts, any random or systematic errors interjected by an automated system, properly employed, will be negligible.

An automated system such as that used at Rocky Flats Plant can decrease saturated cell intercomparison measurement time as much as 8 to 1 . In addition to decreasing measurement time, decreasing human error becomes a very important side benefit.

The equipment selected was a computer controlled, Data Proof scanner and digital voltmeter system. Residual benefits from such a system include flexible use of personnel, isolation of measurement variables, ease of use, reduced human error, increased data collection for better cell history, and the following of cell recovery after shock. 
RFP-4141

DO NOT MICROFILM
THIS PAGE 
APPENDIX A.

Sample Automated Measurement Program 


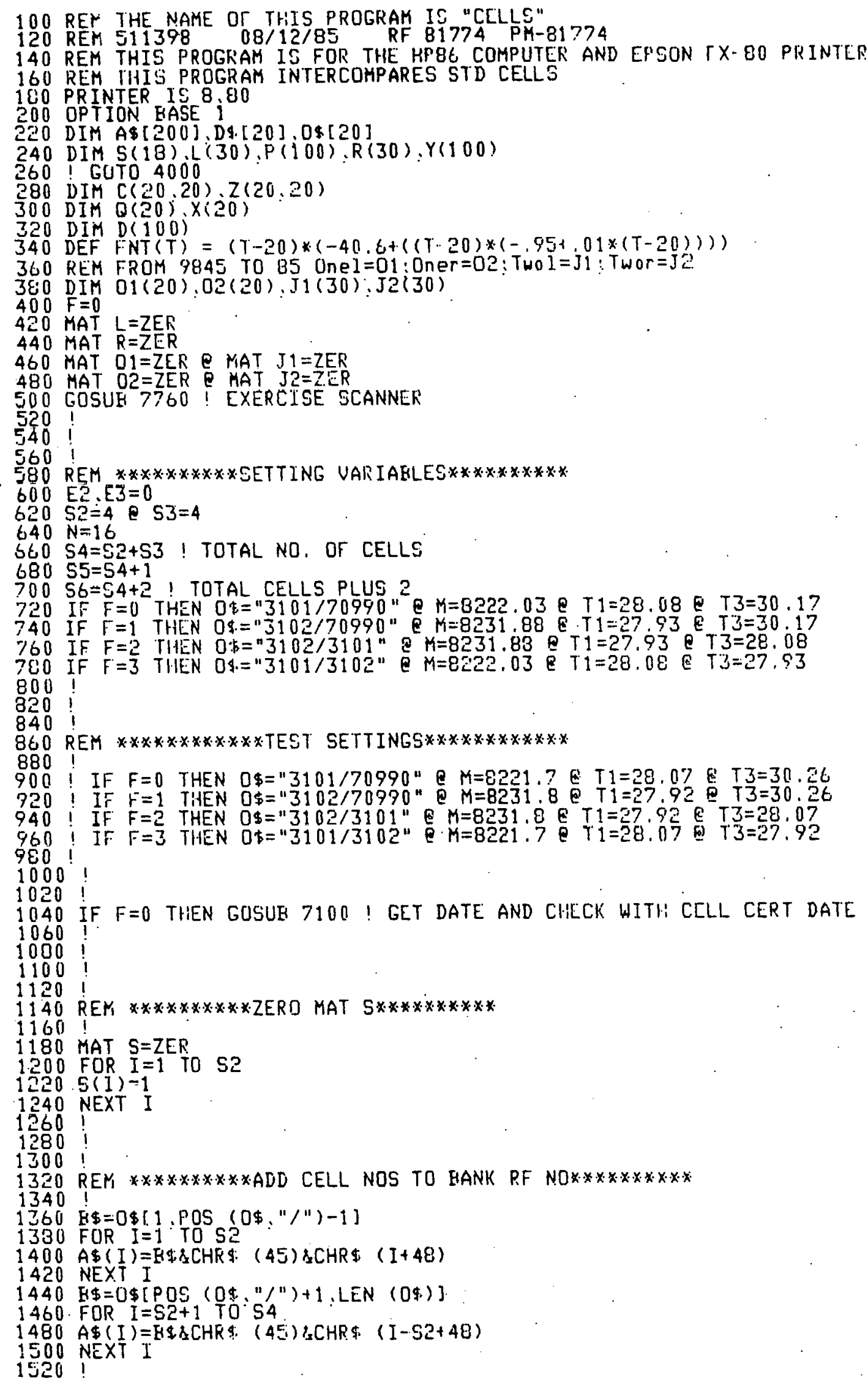


$1540 !$

$1560 \quad$

1580 GOSUE 5380 ! CELL ORDER

1600 !

$1620 \quad 1$

1640 !

1660 REM **********LOADING CELL GRDER INTO MATRIX L AND R************

1680 !

1700 IF $S 2=6$ THEN 1780

1720 MAT $L=D 1$

1760 GOTO 1880

1780 MAT $L=J 1$

1800 MAT $R=J 2$

1820 !

1840

$1860 !$

1880 REM $* * * * * * * * * *$ ENTER TEMP OF CELLS***********

1900 !

1920 IF F>0 THEN GOTO 2200

1940 CLEAR $E$ DISP "ENTER THE FOLLOUING REOUESTED TEMPERATURES IN CENTIGRADE,"

$1960 !$

1980

2000 !

2020 DISP "What is the observed temperature of the RF 3101 cells?"

2040 INPUT TS

2060 IF TS< $=0$ THEN 2020

2080 DISP "What is the observed temperature of the RF 3102 cells?"

2100 INPUT T6

2120 IF T6< $=0$ THEN 2080

2140 DISP "What is the observed temperature of the RF 70990 cells?"

2160 INPUT T7

2180 IF $T\rangle=0$ THEN 2140

2200 IF $F=0$ THEN T2=T5 E T4=T7

2220 IF $F=1$ THEN T2=T6 \& T4=T?

2240 IF $F=2$ THEN T2 $=T 6$ อ TA=T5

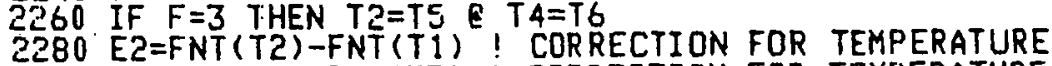

2300 E3=FNT (T4)-FNT(T3) ! CORRECTION FOR TEMPERATURE

2320 !

2340

2360 !

2380 GOSUE 5740 ! COLLECT DIFF READINGS

$2400 !$

2420

2440 !

2460 MAT $Z=Z E R(S 6.56)$

2480 MAT $C=Z E R$ (S6:S6)

2500 MAT $X=Z E R$

2520 MAT $\theta=Z E R$

2540 FOR $\cdot I=1$ TO $N$

$2560^{\circ} Y(I)=P(I)$

2580 IF $L(I)) S 2$ THEN 2640

$2600 Y(I)=Y(I)-E 2$

2620 GOTO 2660

$2640 Y(I)=Y(I)-E 3$

2660 IF $R(I)) S 2$ THEN 2720

$2680 Y(I)=Y(I)+E 2$

2700 GOTO 2740.

$2720 \quad Y(I)=Y(I)+E 3$

$2740 L=L$ (I)

$2760 R=R(I)$

$2780 Q(L)=Q(L)+Y(I)$

$2800 Q(R)=Q(R)-Y(I)$

$2820 Z(L, L)=Z(L, L)+1$

$2840 \quad Z(R: R)=Z(R: R)+1$

$2860 Z(L: R)=Z(L ; R)-1$

$2880 Z(R: L)=Z(R: L)-1$

$2900 Z(55, L)=Z(S 5, L)+1$

$2920 Z(L, S 5)=Z$ (S5:L)

$\left.2540 Z(S)^{5}, R\right)=Z(55 ;)-1$

$29602(k, S 5)=2(55: k)$ 


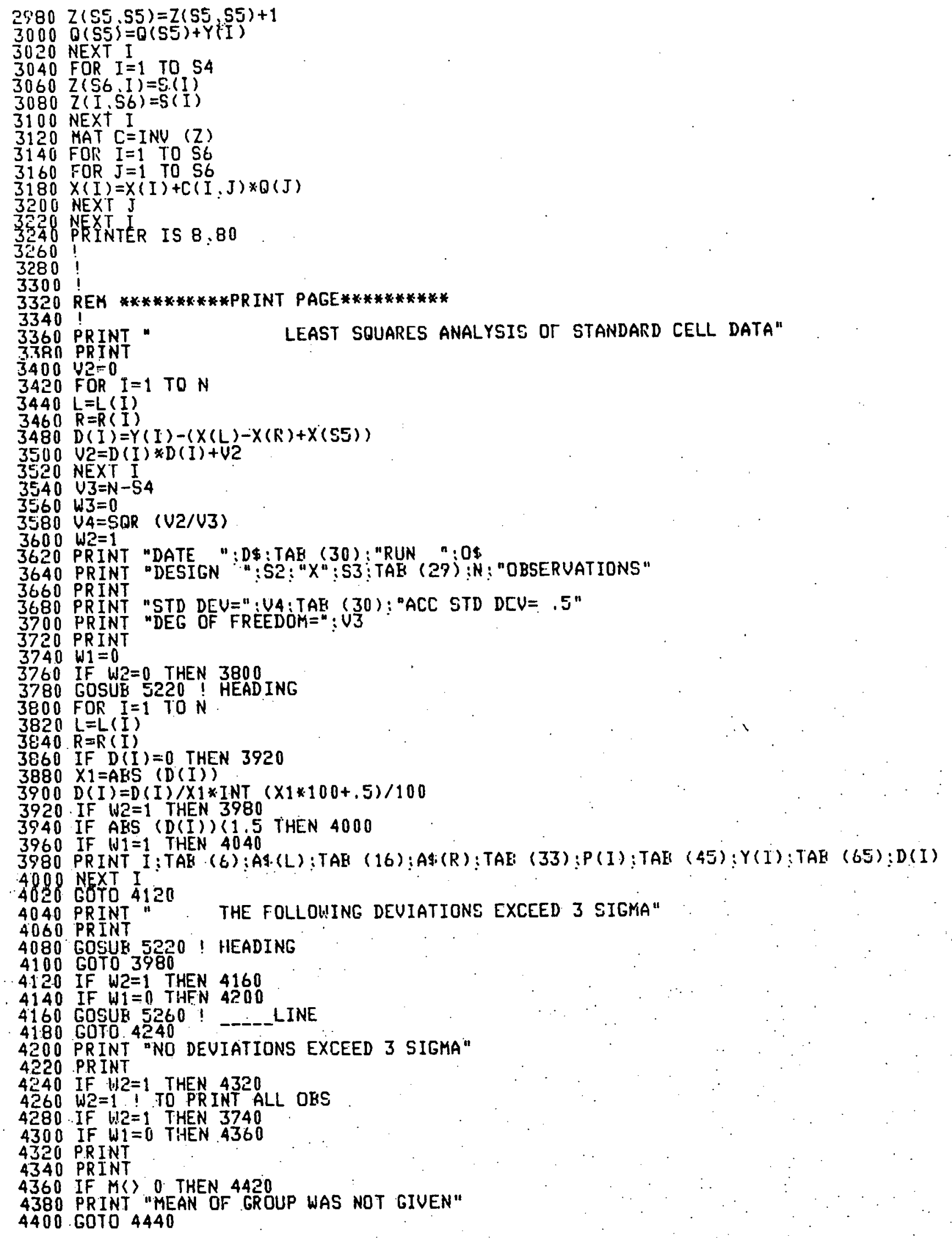




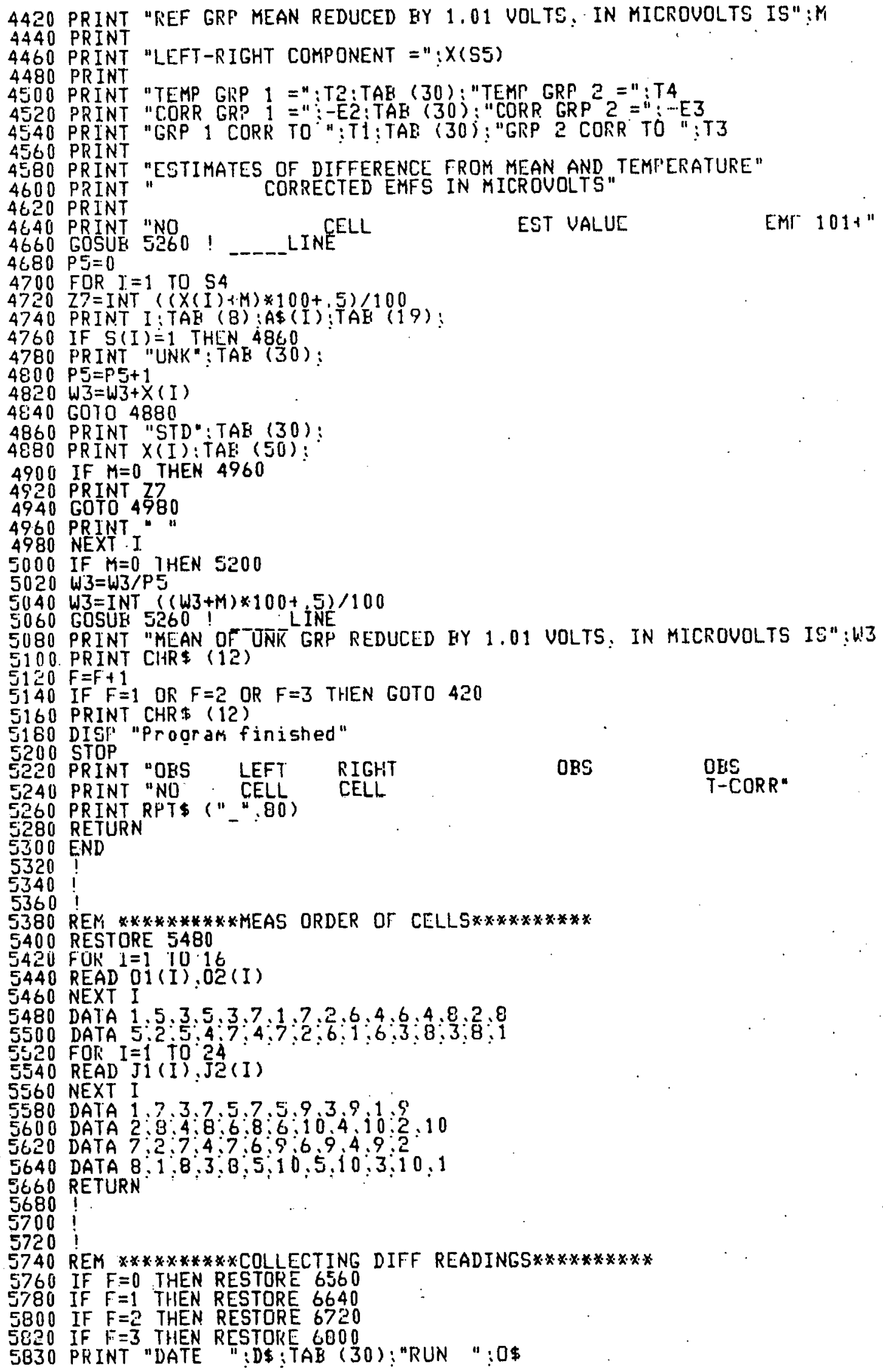


5835 PRINT E PRINT

5840 CUTPUT 705 : "R2X" I $20 \mathrm{MU}$ RANGE

5860 OUTPUT 705 "DOX" I DAMPING OFF

5880 OUTPUT 705 "TOX" ! CONTINUOUS OH TALK

5920 WAIT 500

5940 OUTPUT $724: " \mathrm{E} 16 "$

5960 WAIT 10000

5980 OUTPUT 705 ! "Z1X" ! METER ZERO ON

6000 WAIT 1000

6020 FOR $I=1$ TO 16

6040 DISF I

6060 FOR $K=1$ TO2

6080 READ AS $B$ \%

6100 OUTPUT $724: A 4$

6120 WAIT 500

6140 OUTPUT $724:$ EIS:

6160 HAIT 5000

$6180 \quad P 3=0$

6288 EQR $J=1$ TO 50

$\angle 240 \quad P 3=P Z+P 2(J)$

6260 WAIT 1000

6280 DIGT "J=":J:"DIFF READING = ":P2(J)*1000000

6300 NEXT J

6320 PRINT USING 6340: I.F2(1)*1000000,P2(2)*1000000,P2(3)*1000000,P2(4)*1000000:

$P 2(5) \times 1000000$

6340 IMAGE $10 X, 2 \mathrm{D}, 3 \mathrm{X}, 5(4 \mathrm{D}: 2 \mathrm{D}, 4 \mathrm{X})$

$6360 P 4(K)=P 3 / 5 * 1000000$

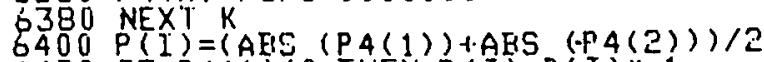

$S 420$ IF $P 4(1)<0$ THEYY $P(I)=P(I) *-1$

6440 DISP " AVE READING = ":P(I)

6460 DUTPUT 724 : "A00"

6480 WAIT 100

6500 OUTPUT 724 : "BOO"

6520 WAIT 100

6540 NEXT I

6560 DATA "A01" "BO9" "A09" "B01": "A03": "BOS", "A09": "E103": "A03": "E11" "A11": "H03":

"A01" "II11" "A11" "BO1"

6580 DATA "AO2" "E110" "A10": "B02": "A04": "B10": "A10": "BO4": "A04": "E12": "A12": "B04":

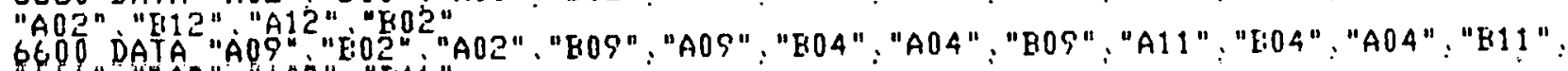

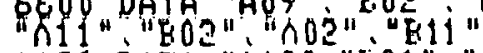

G620 DATA "A10" "LO1" "A01": "B10": "A10": "B03": "A03": "B10": "A12": "E03": "A03": "B12":

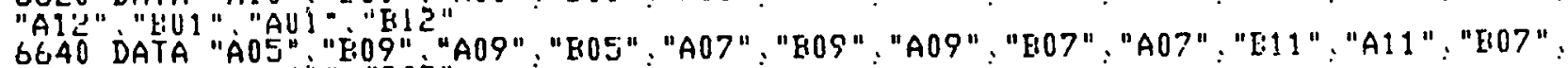
"AOS " "H11 " "A1广" "BOS"

6660 DATA "A06" "E10" "A10": "B06": "A08": "E10": "A10": "B08": "A08": "E12": "A12": "EOE": "A06" "B12". "A12". "BOG"

6680 DATA "AO9" "EO6": "A06": "B09": "A09": "B08": "A08": "BOS": "A11 " :BOS": "A08": "B11": "A11" "BOE" "AOG". "E11"

6700 DATA "A10" "EOS": "A05": "B10": "A10": "E107": "A07": "B10": "A12": "BO7": "A07": "E112": "A12" "Kก: " "AกS". "K12"

6720 DATA "A05" "BO1" "A01": "H05": "A07": "EO1": "AO1": "BO7": "A07": "E03": "A03": "E07": "AO5" "BO3". "A03". "BOS"

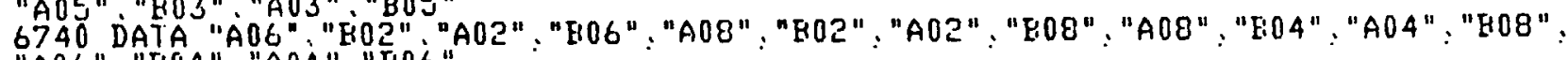
"A06". "HO4". "A04". "BO6"

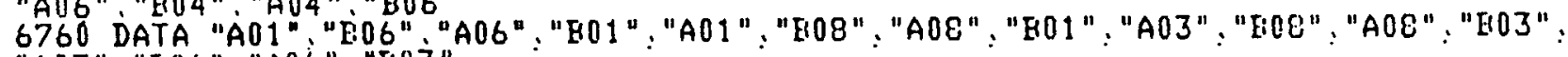
"A03" "EO6" "A06" "KO3"

6780 DATA "AO2" "HOS" "A05": "H02": "A02": "B07": "A07": "B02": "A04": "E07": "A07": "EO4" : "AO4" "GOS" "AO5" "BO4" "A01". "B07" "A07". "BO1"

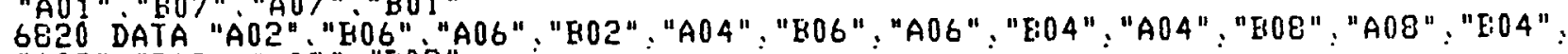
"AO2" "EOE" "AO8" "BOZ"

6840 DATA "AOS" "BO2" "A02" "B05" "A05": "BO4": "A04": "BO5": "A07": "EO4": "A04": "EOO" : "A07" "HOC", "A02" "BO7"

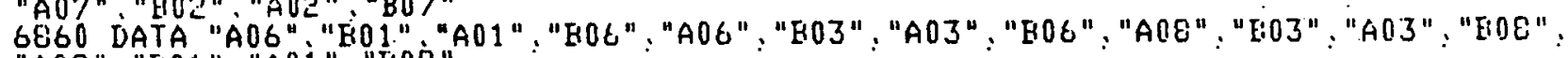
"AO8" "EO1". "AOI" "BOB"

6880 DUTPUT 724 : $A 00 "$

6900 OUTPUT $724: " \mathrm{BOO}$ 


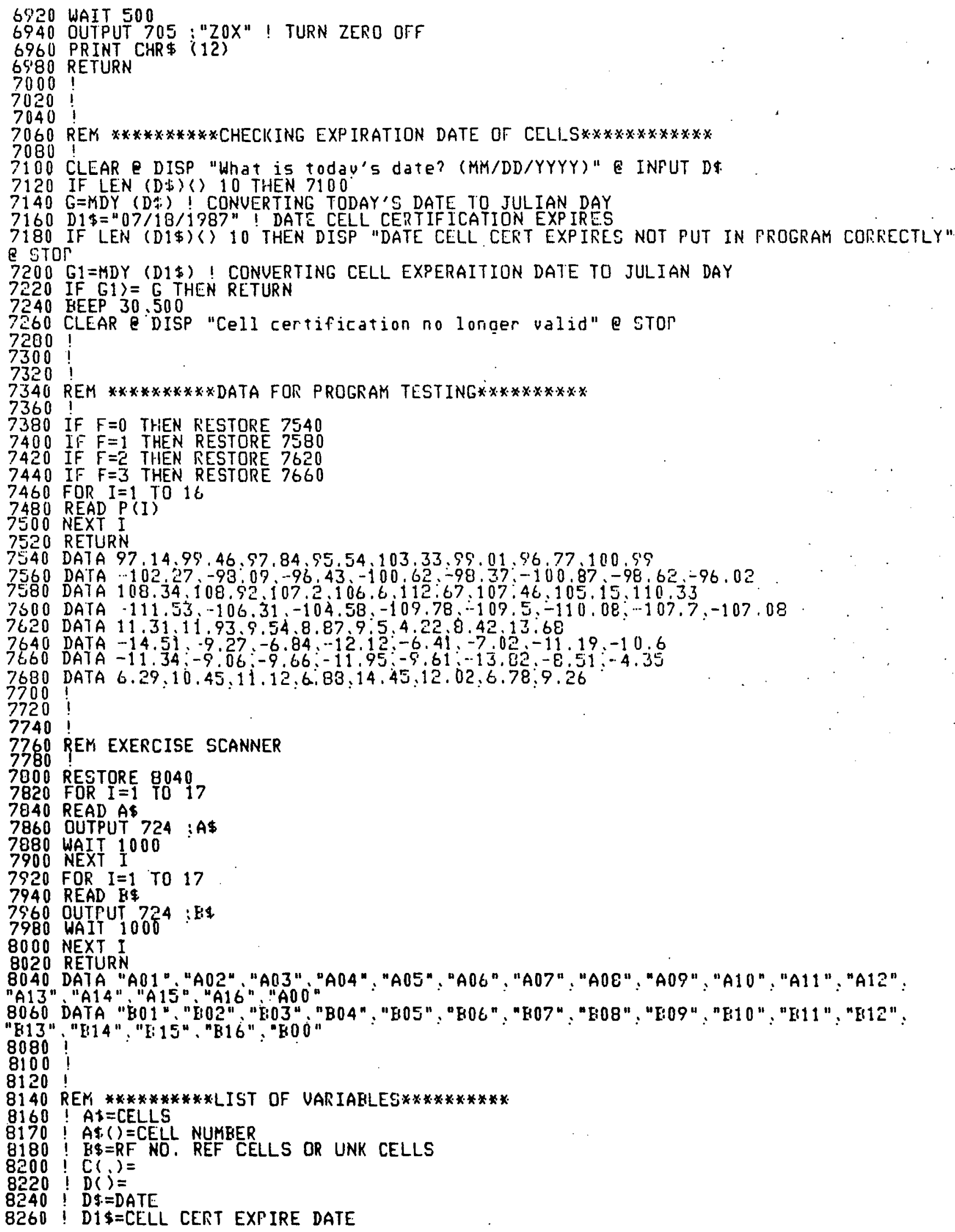




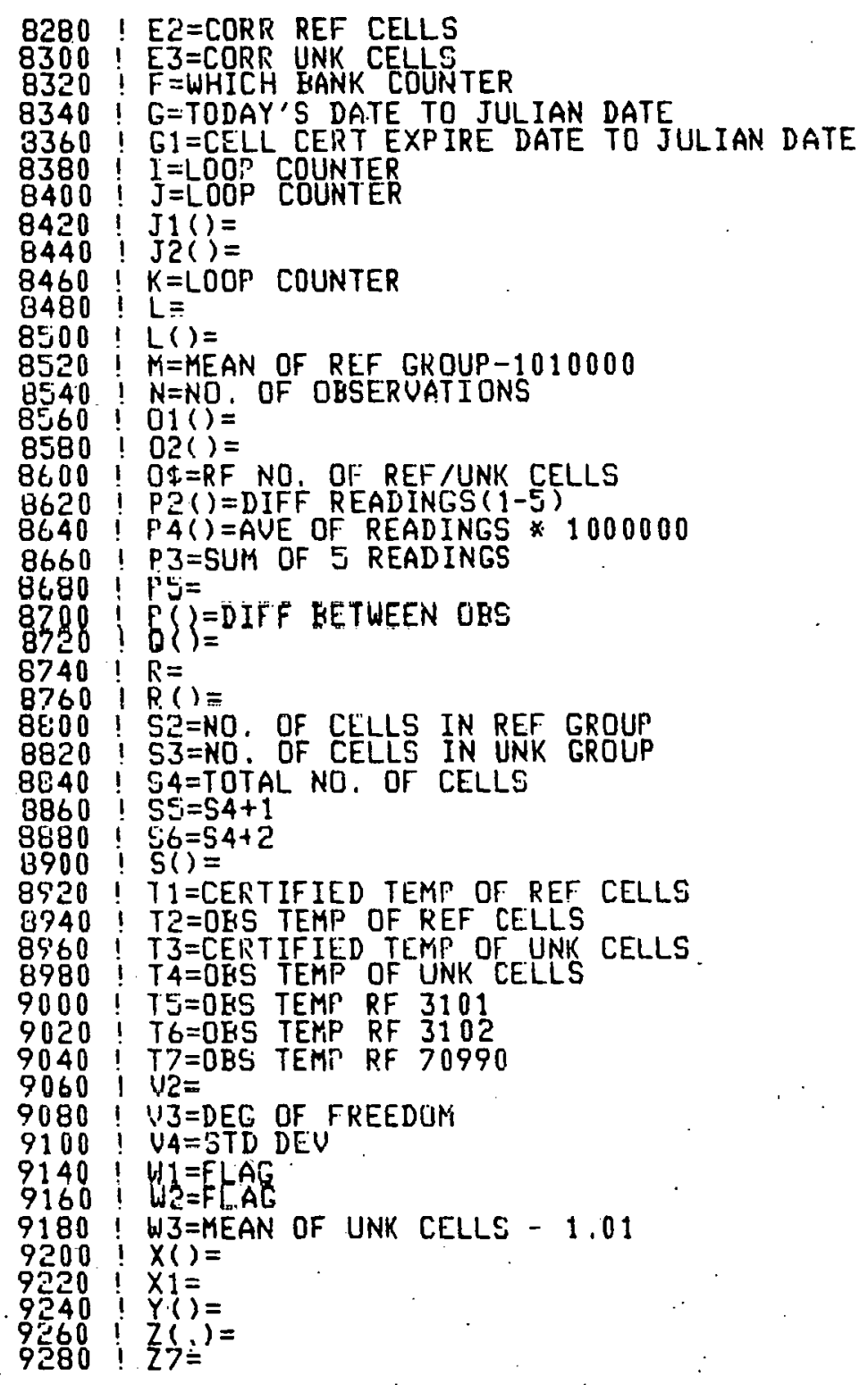


